\title{
Self-compatibility in Lolium temulentum L: its genetic control and transfer into $L$. perenne L. and L. multiflorum Lam
}

\author{
D. THOROGOOD \& M. D. HAYWARD \\ AFRC Institute of Grassland and Environmental Research, Welsh Plant Breeding Station, Plas Gogerddan, Aberystwyth, \\ Dyfed SY23 3EB, UK
}

\begin{abstract}
The segregation of self-compatibility from $L$. temulentum was examined in backcross generations derived from hybrids between this species and the self-incompatible species, $L$. perenne and $L$. multiflorum, the latter being used as recurrent parents. Segregation patterns for self-compatibility were determined by percentage self seed set and by in-vitro self-pollination scores in the resulting backcross generations. Self-compatibility in L. temulentum is controlled in a gametophytic manner by a single gene mutation of either the $Z$ locus or a locus tightly linked to it. Self-compatibility can be fixed in the homozygous form (i.e. 100 per cent pollen-tube growth on selfed stigmas) by selfing half compatible backcross plants. The $S$ locus is still present in L. temulentum and functions when combined with a functional $Z$ locus derived from either $L$. perenne or L. multiflorum. This has evolutionary significance for the relationship of the self-compatible and -incompatible Lolium species.
\end{abstract}

Keywords: incompatibility, Lolium multiflorum, Lolium perenne, Lolium temulentum, selfcompatibility.

\section{Introduction}

The two locus $(S, Z)$ multi-allelic, gametophytic incompatibility system has been found to operate in most outbreeding grasses including the agriculturally important Lolium perenne (Cornish et al., 1979) and $L$. multiflorum (Fearon et al., 1983). This system, although normally very efficient, occasionally breaks down such that self seed may be produced. Enforced selfing of plants can result in seletion of genotypes capable of self-fertilization (Jones \& Jenabzadeh, 1981). One inbred line of $L$. perenne has been shown to posses a single gene mutation, independent of the $S$ and $Z$ loci, which acted gametophytically such that, on selfing, only pollen grains that possess the mutated allele $\left(\mathbf{S c}^{1}\right)$ were able to penetrate the style and effect fertilization (Thorogood \& Hayward, 1991). In addition, within the Lolium genus, naturally self-fertile species occur, such as L. temulentum, which hybridize relatively easily with both $L$. perenne and $L$. multiflorum (Jenkin, 1935,1954). Unilateral incompatibility (UI), a genetic mechanism which isolates self-incompatible and self-compatible species, is rarely encountered in the Lolium genus and so should not present a barrier to the transfer of self-compatibility genes from one species to another. Indeed, Nitzsche (1983) has shown that such transfer can be effected between $L$. temulentum and $L$. perenne. However, to increase the efficiency of transfer for the production of self-fertile lines of the two agricultural species, it is necessary to have information on the genetic control of self-compatibility. Such knowledge may also indicate the mode of evolution of self-compatibility in the Lolium genus.

The experiments described here follow the segregation of self-compatibility through the early generations obtained by backcrossing the hybrids, L. temulentum $\times L$. perenne or $L$. multiflorum, to the outbreeders as recurrent parents (RPs) and examines the relationship of self-compatibility to the $S Z$ incompatibility system.

\section{Hypotheses for the control of self- compatibility in L. temulentum}

Self-fertility is generally regarded as a derived condition (Jeffery, 1916; Ames, 1939) and has arisen as an essential step in the colonization of new habitats where the initial absence or scarcity of other pollen parents 
would otherwise prevent a further spread and success of the immigrant species (Stebbins, 1957). Jenkin (1935) suggested that $L$. temulentum is derived from $L$. perenne. Until now, the genetic control of self-compatibility in $L$. temulentum has been unknown, although a number of models, from knowledge of the functioning of the two locus incompatibility system in Lolium spp. and of the evolutionary relationships between self-fertile and self-incompatible species in general, may be proposed.

\section{Model 1}

It has been suggested by Nitzsche (1983) that selfcompatibility in $L$. temulentum arose due to the absence or inactivation of both self-incompatibility loci. If this is the case, assuming that the genes act gametophytically, backcross families produced by crossing $L$. temulentum $\times L$. perenne or $L$. multiflorum $F_{1}$ hybrids to self-incompatible $L$. perenne or $L$. multiflorum plants would give rise to 1:2:1 ratios of selfincompatible $(-)$, half $(\mathrm{H})$ self-compatible and three-quarters ( $\mathrm{T}$ ) self-compatible plants (Table 1 ). If we assume that the self-incompatible parent used was heterozygous at both incompatibility loci, 64 possible backcross genotypes would be formed. Sixteen of these would possess fully functional incompatibility alleles

Table 1 Model 1. Compatibility genotypes obtained on crossing plants with and without incompatibility alleles and when backcrossing the hybrids to self-incompatible plants

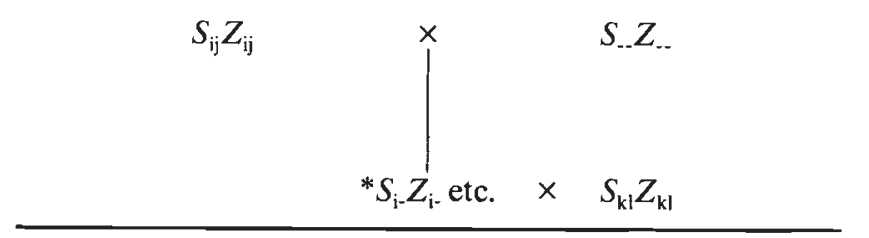

\begin{tabular}{|c|c|c|c|c|c|c|}
\hline & \multicolumn{5}{|l|}{ ర } \\
\hline & & $S_{\mathrm{k}} Z_{\mathrm{k}}$ & $S_{\mathrm{k}} Z_{1}$ & $S_{1} Z_{\mathrm{k}}$ & $S_{1} Z_{1}$ & \\
\hline \multirow{4}{*}{ } & $S_{\mathrm{i}} Z_{\mathrm{i}}$ & $S_{i \mathrm{k}} Z_{\mathrm{ik}}$ & $S_{\mathrm{ik}} Z_{\mathrm{il}}$ & $S_{\mathrm{i} \mid} Z_{\mathrm{ik}}$ & $S_{\mathrm{i}} Z_{\mathrm{il}}$ & $(-)$ \\
\hline & $S_{\mathrm{i}} Z$ & $S_{\mathrm{ik}}^{\mathrm{n}} Z_{-\mathrm{k}}$ & $S_{\mathrm{ik}} Z_{-1}^{\prime \prime}$ & $S_{\mathrm{i} \mid} Z_{-\mathrm{k}}$ & $S_{\mathrm{il}} Z_{-1}$ & $(\mathrm{H})^{\prime}$ \\
\hline & $S . Z_{\mathrm{i}}$ & $S_{-\mathrm{k}} Z_{\mathrm{ik}}$ & $S_{-\mathrm{k}} Z_{i 1}$ & $S_{-1} Z_{\mathrm{ik}}$ & $S_{-1} Z_{\mathrm{il}}$ & $(\mathrm{H})$ \\
\hline & $S . Z$ & $S_{-k} Z_{-k}$ & $S_{-\mathrm{k}} Z_{-1}$ & $S_{-1} Z_{-k}$ & $S_{-1} Z_{-1}$ & (T) \\
\hline
\end{tabular}

$-=S \mathrm{I}: \mathrm{H}=$ half $S \mathrm{C}: \mathrm{T}=$ three-quarters $S \mathrm{C}$.

$$
1: 2: 1
$$

${ }^{*}$ Four different $F_{1}$ genotypes may be obtained, each giving rise to a different range of genotypes on backcrossing but which display the same pattern of segregation of selfincompatible to half and three-quarter self-compatible plants. (therefore self-incompatible), 16 would possess a nonfunctional allele at both $S$ and $Z$ loci and a further 32 would possess a non-functional allele at either the $S$ or the $Z$ locus. On male gamete formation, any pollen grain with a non-functional $S$ or $Z$ allele would cause the incompatibility reaction to break down as alleles at both loci are required to be matched in the pollen and the stigma for an incompatibility reaction to occur (Hayman, 1956). Thus, those plants with a single nonfunctional $S$ or $Z$ allele would be half self-compatible and those with a non-functional $S$ and $Z$ allele would be three-quarters self-compatible.

\section{Model 2}

It is possible that self-compatibility in L. temulentum, as a step to colonization of new habitats, may have arisen by a single gene mutation of one of the incompatibility loci.

\section{Model 3}

Self-compatibility may have arisen as a single epistatic gene, independent of the two incompatibility loci, which overrides the action of the $S$ and $Z$ loci.

These two single gene models assume that selfcompatibility is controlled either gametophytically or in a combined sporophytic/gametophytic manner, whereby only pollen that possesses the selfcompatibility gene is capable of affecting self-pollination, yet on the female side both the compatibility and the incompatibility factors are transmitted. Similar models were earlier proposed for the control of selfcompatibility in an inbred line of $L$. perenne in which segregation for self-compatibility was assessed in $F_{1}, F_{2}$ and $\mathrm{F}_{3}$ generations following the crossing of the selffertile line with a self-incompatible line (Thorogood \& Hayward, 1991). An alternative method proposed to study the genetic control of self-compatibility in $L$. temulentum would be to follow segregations for selfcompatibility in backcross generations following the initial production of the $F_{1}$ hybrids. On both single gene models, two classes of compatibility can be expected to occur in each backcross generation. The $\mathrm{F}_{1}$ hybrids, heterozygous for a single self-incompatible gene, when backcrossed to an unrelated self-incompatible recurrent parent, would produce progeny both with and without the self-compatibility allele in equal proportions. The self-fertile backcross plants would be heterozygous and therefore would give a half selfcompatible reaction. The remaining backcross plants would not possess a self-compatible allele and therefore would give a self-incompatible $(-)$ reaction. The advantage of this type of segregation is that not only 
can the two compatibility types be distinguished by carrying out in-vitro self-pollinations but percentage seed-set on selfing plants, under isolating conditions, would confirm the two classes.

The two single gene models can be distinguished by carrying out pollinations between self-fertile $\mathrm{BC} 1$ plants and the original recurrent parents (RP) used to produce them. With a self-compatibility mutation of either the $S$ or $Z$ locus, backcross pollinations can only give rise to three-quarters compatibility (Table 2a). However, when a separate self-compatibility locus is involved, which segregates independently of the two incompatibility loci, the backcross pollinations would show a reciprocal difference in compatibility proportions. When the self-fertile $\mathrm{BC} 1$ plant is the pollinator, seven-eighths $(7 / 8)$ compatibility would be expected whereas the reciprocal would exhibit a three-quarters compatible reaction. The self-incompatible $\mathrm{BC} 1$ plants would give reciprocal three-quarters compatible reactions with their RP (Table 2b).

\section{Mode/ 4}

Self-compatibility may also have arisen by the accumulation of polygenic modifiers, in which case selfcompatibility in the first backcross generation would

Table 2(a) Backcross pollinations expected when $F_{1}$ plants possess a heterozygous self-compatibility mutation at the $Z$ locus

\begin{tabular}{|c|c|c|c|c|}
\hline \multirow[b]{2}{*}{$F_{1}=S_{i j} Z_{-i}$} & & \multicolumn{3}{|l|}{0} \\
\hline & & $\begin{array}{l}\mathrm{RP} \\
S_{\mathrm{kl}} Z_{\mathrm{kl}}\end{array}$ & $\begin{array}{l}S C \text { BC1 } \\
S_{\text {ik }} Z_{-k} \text { etc. }\end{array}$ & $\begin{array}{l}S I \mathrm{BC} 1 \\
S_{\mathrm{ik}} Z_{\mathrm{ik}} \text { etc. }\end{array}$ \\
\hline \multicolumn{5}{|l|}{ \% } \\
\hline $\mathrm{RP}$ & $S_{\mathrm{kl}} Z_{\mathrm{kl}}$ & - & $\mathrm{T}$ & $\mathrm{T}$ \\
\hline$S C B C 1$ & $S_{\mathrm{ik}} Z_{-\mathrm{k}}$ etc. & $\mathrm{T}$ & & \\
\hline$S I \mathrm{BC} 1$ & $S_{\mathrm{ik}} Z_{\mathrm{ik}}$ etc. & $\mathbf{T}$ & & \\
\hline
\end{tabular}

Table 2(b) Backcross pollinations expected when $F_{1}$ plants possess a heterozygous self-compatibility mutation at a locus separate to $S$ or $Z$

\begin{tabular}{|c|c|c|c|c|}
\hline \multirow{2}{*}{\multicolumn{2}{|c|}{$\mathrm{F}_{1}=S_{\mathrm{ij}} Z_{\mathrm{ij}} \mathrm{Ff}$}} & \multicolumn{3}{|l|}{0} \\
\hline & & $\begin{array}{l}\mathrm{RP} \\
S_{\mathrm{k} \mid} Z_{\mathrm{kl}} \mathrm{ff}\end{array}$ & $\begin{array}{l}S C \text { BC } 1 \\
S_{\mathrm{ik}} Z_{\mathrm{ik}} \text { Ff etc. }\end{array}$ & $\begin{array}{l}S I \text { BC1 } \\
S_{\mathrm{ik}} Z_{\mathrm{ik}} \text { ff etc. }\end{array}$ \\
\hline \multicolumn{5}{|l|}{ q } \\
\hline $\begin{array}{l}\text { RP } \\
\text { SC BC1 } \\
\text { SI BC1 }\end{array}$ & $\begin{array}{l}S_{\mathrm{k}} Z_{\mathrm{k} k \mathrm{ff}} \\
S_{\mathrm{ik}} Z_{i \mathrm{k}} \text { Ff etc. } \\
S_{\mathrm{ik}} Z_{\mathrm{ik}} \text { ff etc. }\end{array}$ & $\begin{array}{l}\overline{\mathrm{T}} \\
\mathrm{T}\end{array}$ & $7 / 8$ & $\mathrm{~T}$ \\
\hline
\end{tabular}

be expressed as a continuous distribution of plants ranging from low or zero self-compatibility up to 100 per cent self pollen-tube growth. Alternatively, first backcross generation plants may not possess enough of the $L$. temulentum genome to allow expression of selfcompatibility at all. This would be especially so if genes essential for the expression of self-compatibility were spread throughout the L. temulentum genome. Clearly, from a practical point of view, transfer of polygenically controlled self-compatibility may be less feasible and more unpredictable than if it is controlled by only a few genes.

\section{Materials and methods}

$F_{1}$ hybrids between $L$. temulentum on the one hand and $L$. perenne and $L$. multiflorum on the other (produced by Dr G. M. Evans, Department of Agricultural Science, University of Wales, Aberystwyth) were used as the female recipient parent on to which recurrent $L$. perenne and $L$. multiflorum parents were backcrossed. The hybrid plants (Table 3 ) were produced by crossing hand-emasculated $\mathrm{Ba} 3081 \mathrm{~L}$. temulentum plants with $L$. perenne and $L$. multiflorum plants and culturing resultant embryos on a modified Gamborg and Miller B5 medium.

In order to aviod the possibility of cross-incompatibility on backcrossing, the RP plants were not of the same incompatibility genotype as the self-incompatible parents used to produce the original hybrids but had similar flowering dates so that no problems with synchronizing for crossing occurred. They were also practically self-incompatible, although some plants produced a small number of self seed when bagged as isolated units. The L. multiflorum variety, $\mathrm{Bb} 2067$, was used as the pollen parent to backcross on to the ' $\mathrm{A}$ ' and ' $C$ ' hybrids, $L$. perenne cv Cropper on to the ' $D$ ' and ' $F$ ' hybrids and $L$. perenne cv Aurora on to the ' $E$ ' hybrids.

Two cycles of backcrossing were carried out and, in addition, each backcross was selfed, by bagging inflorescences from plants as single selfing units, to produce the $\mathrm{BC} 1 \mathrm{~S} 1$ generation to assess the segregation of

Table 3 Hybrid plant material

\begin{tabular}{lll}
\hline $\begin{array}{l}\text { Cross } \\
\text { type }\end{array}$ & $\begin{array}{l}\text { Number of } \\
\text { plants }\end{array}$ & Pedgree \\
\hline A & 20 & Ba3081 $\times($ Bb1232 $/ 4 \times$ Titania $)$ \\
C & 20 & Ba3081 $\times($ Bb1232/4 $\times$ Trident $)$ \\
D & 20 & Ba3081 $\times($ Lp19 $\times$ S24 $)$ \\
E & 20 & Ba3081 $\times($ Lp19 $\times$ Aurora $)$ \\
F & 6 & Ba3081 $\times($ Lp19 $\times$ Premo $)$ \\
\hline
\end{tabular}


self-compatibility genes as determined by the seed set data. $\mathrm{BC} 1$ progeny were obtained by embryo-culture or from mature seed and subsequent generations were obtained from mature seed only.

In-vitro self pollinations of $\mathrm{BC} 1$ and $\mathrm{BC} 1 \mathrm{~S} 1$ plants, and cross-pollinations between $\mathrm{BC} 1$ plants and the $\mathrm{RP}$ genotypes used to produce them, were carried out using the Petri-dish method of Lundqvist (1961) and analysed using the aniline blue fluorescence technique of Lalouette (1967).

Isozyme phenotypes of $\mathrm{BC} 1$ plants at five loci, namely $P G 1 / 2, G O T / 2, G O T / 3, A C P / 2$ and $S O D$ were determined using electrophoretic separation systems developed for the forage grasses by Hayward \& McAdam (1977) in order to investigate the possibility of linkage between these loci and any L. temulentumderived self-compatibility genes.

\section{Results}

The $\mathrm{F}_{1}$ hybrid plants were, as expected, male-sterile (Jenkin, 1935, 1954) but backcross progeny could be obtained by using these hybrids as female parents.

The first generation back-crosses to $L$. multiflorum (Bb2067) yielded 18 plants all of which were malefertile with fully dehiscent anthers producing plentiful quantities of pollen. The L. perenne cv Aurora backcrosses were less successful, with only 22 of the 52 plants producing enough viable pollen to effect fertilization. Not one of the 14 backcross plants resulting from 'D'-type hybrids produced dehiscent anthers. Of the $40 \mathrm{BC} 1$ plants from which viable pollen could be collected, 21 were fully self-incompatible and 19 showed some self-compatible grains on in-vitro selfpollination. These results fit a $1: 1$ ratio $(\mathbf{P}>0.80)$ as proposed in models 2 and 3 and give significant deviation from the 1:3 ratio $(\mathrm{P}<0.001)$ expected on model 1 (Table 4).

Counts of compatible and incompatible pollen grains of two of these self-fertile $\mathrm{BC} 1$ plants were carried out after in-vitro self-pollination. A large proportion of inviable pollen grains showing no fluorescence reaction made counts difficult in other cases. All pollinations could be classified as half self-compatible with most pollinations giving segregation ratios that differed significantly from a 1:3, SI:SC ratio but with all pollinations agreeing with a 1:1 ratio (Table 5).

Self-compatibility is ultimately expressed in terms of the number of florets setting seed in the absence of pollen from other plants. None of the self-incompatible $\mathrm{BC} 1$ plants produced more than 0.67 per cent (5) seeds, whereas those plants classified as self-fertile gave a range of seed set figures from 1.41 to 53.57 per cent. Thus percentage seed set agreed fully with the compatibility status of the plants as classified by invitro self-pollination (Fig. 1).

Table 4 Number of self-incompatible, self-fertile and male-sterile plants in BC1 and $\mathrm{BC} 2$ generations

\begin{tabular}{|c|c|c|c|c|c|}
\hline $\begin{array}{l}\text { Cross } \\
\text { type }\end{array}$ & $\begin{array}{l}\text { Self } \\
\text { in-compatible }\end{array}$ & $\begin{array}{l}\text { Self- } \\
\text { compatible }\end{array}$ & $\begin{array}{l}\text { Model } 1 \\
\chi^{2}(1: 3)\end{array}$ & $\begin{array}{l}\text { Models } \\
2 \text { and } 3 \\
\chi^{2}(1: 1)\end{array}$ & $\begin{array}{l}\text { Number of } \\
\text { male-sterile } \\
\text { plants }\end{array}$ \\
\hline \multicolumn{6}{|l|}{$\mathrm{BC} 1^{\dagger}$} \\
\hline A & 4 & 8 & $0.11^{\mathrm{ns}}$ & $0.75^{\mathrm{ns}}$ & - \\
\hline $\mathrm{C}$ & 4 & 2 & $3.56^{\mathrm{ns}}$ & $0.17^{\mathrm{ns}}$ & - \\
\hline $\mathrm{D}$ & - & - & & & 14 \\
\hline $\mathrm{E}$ & 12 & 9 & $9.92^{* * *}$ & $0.19^{\text {ns }}$ & 23 \\
\hline$F$ & 1 & - & & & - \\
\hline Total & 21 & 19 & $14.70^{* * *}$ & $0.02^{\mathrm{ns}}$ & 37 \\
\hline \multicolumn{6}{|l|}{$\mathrm{BS} 2+\dagger$} \\
\hline A & 16 & 19 & $6.94^{* *}$ & $0.11^{\mathrm{ns}}$ & - \\
\hline $\mathrm{C}$ & 7 & 3 & $8.53 * *$ & $0.90^{\mathrm{ns}}$ & - \\
\hline $\mathrm{E}$ & 13 & 12 & $8.33^{* *}$ & $0.00^{\text {ns }}$ & - \\
\hline Total & 36 & 34 & $24.69^{* * *}$ & $0.01^{\mathrm{ns}}$ & - \\
\hline $\begin{array}{l}* *=\text { Sign } \\
* * *=\text { Sig } \\
\text { ns = No } \\
\dagger \text { Based o } \\
\dagger \dagger \text { Based }\end{array}$ & $\begin{array}{l}\text { nt difference } \\
\text { ant difference } \\
\text { ficant differen } \\
\text {-vitro self-pol } \\
\text { eed set data o }\end{array}$ & $\begin{array}{l}\text { er cent leve } \\
1 \text { per cent le } \\
\text { om expected } \\
\text { on scores. } \\
\text { lants derive }\end{array}$ & io. & $D C$ & \\
\hline
\end{tabular}


Some of the $\mathrm{BC} 2$ seed was sown and plants, when not produced from emasculated crosses, were identified as resulting from $\mathrm{BC} 1 \times \mathrm{RP}$ crosses and reciprocals by the use of isozyme markers. The overall fertility of the plants was vastly increased with no malesterile plants being identified.

In the $\mathrm{BC} 1$ generation, the percentage self seed set agreed perfectly with the in-vitro pollination scores and thus in the $\mathrm{BC} 2$ generation it was considered necessary to obtain seed set data only. Five $\mathrm{BC} 2$ plants from each of 14 self-fertile $\mathrm{BC} 1$ plants were selfed, five plants being a large enough sample to obtain at least one selfincompatible and one self-fertile segregant in 95 per cent of cases if a 1:1 ratio (models 2 or 3 ) is expected. If plants segregate according to model 1 , there would be

Table 5 Number of self-incompatible and self-compatible grains in self-compatible $\mathrm{BC} 1$ plants

\begin{tabular}{lrrrl}
\hline & & & $\begin{array}{l}\chi^{2} \\
1: 3 \\
\text { Cross type }\end{array}$ & \multicolumn{2}{c}{ SI } & SC & $\begin{array}{l}\chi^{2} \\
\text { (model 1) }\end{array}$ & $\begin{array}{l}\text { (model 2) } \\
\text { (m) }\end{array}$ \\
\hline A & 154 & 129 & $129.05^{* * *}$ & $2.04^{\text {ns }}$ \\
C & 51 & 58 & $46.29^{* * *}$ & $0.33^{\text {ns }}$ \\
E & 74 & 66 & $56.47^{* * *}$ & $0.35^{\text {ns }}$ \\
Total & 279 & 253 & $212.23^{* * *}$ & $1.17^{\text {ns }}$ \\
\hline
\end{tabular}

ns $=$ No significant difference from expected ratio. $* * *=$ Significant difference at 0.1 per cent level. an approximately 25 per cent chance of obtaining families with no self-incompatible segregants. Thus such an absence would be likely to occur in about three of the 14 families selected and tested. With an arbitrary level of 1 per cent self seed set to distinguish selfincompatible from -fertile plants, every self-fertile plant produced at least one self-incompatible and one self-fertile plant. The overall segregation of the $\mathrm{BC} 2$ agreed closely with a 1:1 ratio (Table 4). The percentage seed set figures of the self-fertile plants followed a normal distribution and data for all $\mathrm{BC} 2$ plants indicated a clear bimodal distribution into self-incompatible and self-fertile plants (Fig. 2). Mean seed set was increased in the $\mathrm{BC} 2$ self-fertile plants $(\mathrm{BC} 1=16.45$ per cent, $\mathrm{BC} 2=37.02$ per cent $)$.

Three $\mathrm{BC} 2$ plants from each of 21 self-incompatible $\mathrm{BC} 1$ plants were also selfed, of which nearly 80 per cent (50 plants) were also self-incompatible. The remaining 13 plants, each derived from one of eight of the $\mathrm{BC} 1$ plants, produced between 7.11 and 50.62 per cent self seed, enough to consider them as self-fertile. Furthermore, there was no obvious relationship between the level of pseudo-self-compatibility (characterized by low self seed set) shown by some of the selfincompatible $\mathrm{BC} 1$ plants and the high level of self-fertility in their $\mathrm{BC} 2$ derivatives.

Forty-one progeny resulting from the selfing of selffertile $\mathrm{BC} 1$ plants were tested for a self pollen/stigma reaction (Table 6). Pollen quality was poor in some of the pollinations. Some pollen grains exhibited a diffuse
Fig. 1 Percentage seed set by $\mathrm{BC} 1$ plants. (ㅁ) S1 BC1 selfed, ( ) SC BC1 selfed.

Fig. 2 Percentage seed set by BC2 plants derived from SCBC1 plants.
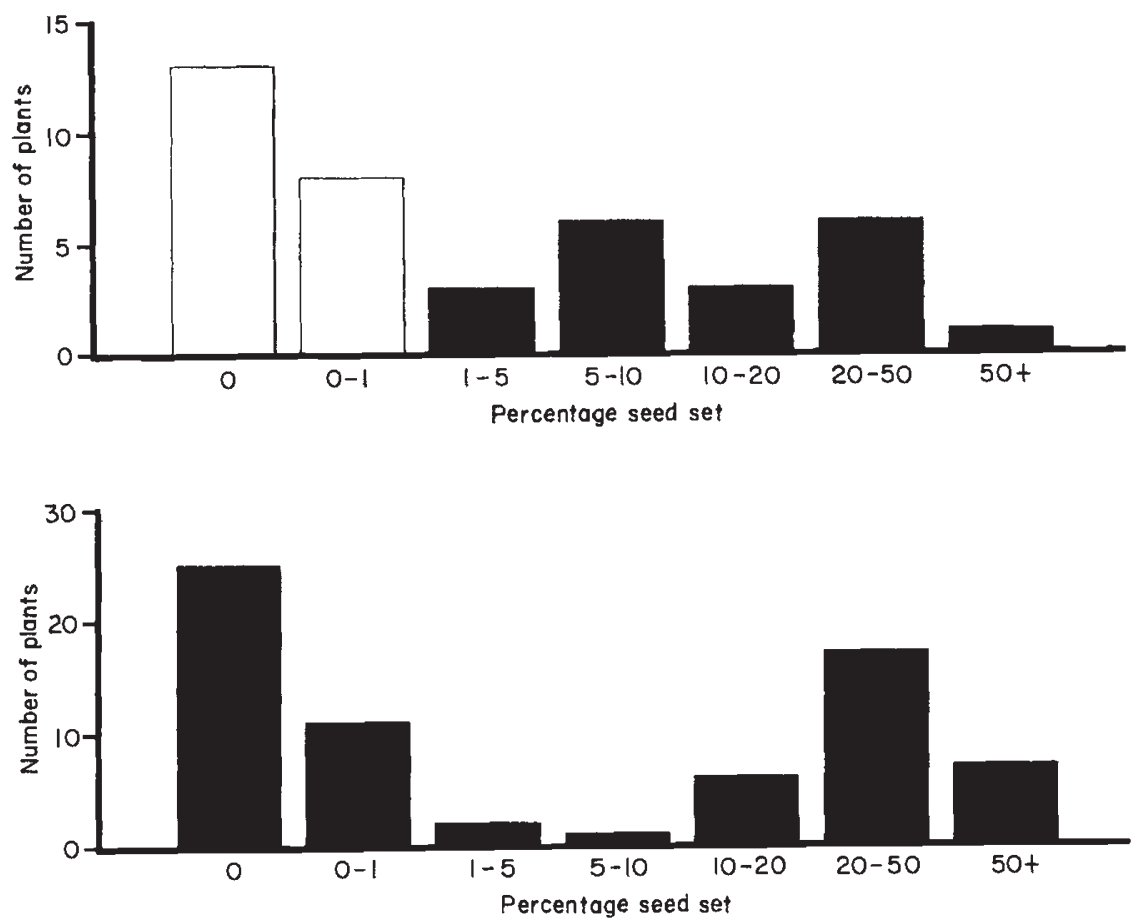
Table 6 Self pollen reaction of some BC1S1 plants

\begin{tabular}{lcc}
\hline BC1 plant & $\begin{array}{l}\text { Number of partially } \\
\text { self-compatible } \\
\text { plants }\end{array}$ & $\begin{array}{l}\text { Number of fully } \\
\text { self-compatible } \\
\text { plants }\end{array}$ \\
\hline A7/19/7 & 4 & 5 \\
A7/19/9 & 1 & 1 \\
E4/13/1 & 2 & 1 \\
E4/28/11 & 3 & 0 \\
E4/28/19 & 3 & 0 \\
E4/28/23 & 3 & 0 \\
*E6/5/1 & 3 & 4 \\
E6/5/4 & 8 & 1 \\
Total & 27 & 12 \\
\hline
\end{tabular}

*Two plants in this family could not be classified as all pollen grains exhibited a diffuse fluorescence which could not be interpreted as either an incompatible or a compatible grain.

fluorescence and could be classified, on casual observation, as incompatible but, as they did not show any sign of pollen-tube tip growth or the cresent-shaped deposition of callose typical of an incompatible reaction, they were deemed to be inviable. A high proportion of dead pollen in other pollinations did not show any fluorescence reaction. The presence of these inviable pollen grains may have caused an over-estimate of incompatible grains but, even so, a number of fully compatible $(+)$ self pollinations were observed (Table 6).

Eight $\mathrm{BC} 1$ plants resulted from a cross between the hybrid $\mathrm{A} 7 / 19$ and its $\mathrm{RP}, \mathrm{Bb} 2067 / 7 / 3$. The pollen/ stigma reaction of reciprocal crosses between seven of the $\mathrm{BC} 1$ plants and the RP were tested to determine the relationship between self-compatibility and the SZ incompatibility system. Pollen counts were made and the ratios of compatible to incompatible pollen grains consistently agreed with a 3:1 ratio (three-quarters compatible pollen). In no pollination, could a 7:1 ratio (seven-eighths compatible pollen) be fitted satisfactorily (Table 7).

Joint segregations of self-compatibility with the $P G 1 / 2, G O T / 2, G O T / 3, A c P / 2$ and $S O D$ isozyme loci were calcuted for $\mathrm{BC} 1$ plants. A significant joint segregation of the $G O T / 3$ locus with self-compatibility was found where the $L$. temulentum derived 'c' allele was more often than not associated with self-fertile individuals (Table 8).

\section{Discussion}

$L$. temulentum hybridizes relatively easily with $L$. perenne and $L$. multiflorum as either the male or the female parent although embryo-rescue techniques are
Table 7 Segregation of compatible to incompatible (C:I) pollen in backcross pollinations between self-fertile and selfincompatible $\mathrm{BC} 1$ plants used as either male or female parent and their RP plants

\begin{tabular}{lcc}
\hline & C:I grains & $\chi^{2}(3: 1)$ \\
\hline SC BC1 as $0^{\circ}$ & $132: 46$ & $0.07^{\text {ns }}$ \\
SI BC1 as $0^{\circ}$ & $78: 36$ & $2.63^{\text {ns }}$ \\
SC BC1 as $\odot$ & $222: 77$ & $0.16^{\text {ns }}$ \\
SI BC1 as $\odot$ & $161: 61$ & $1.20^{\text {ns }}$ \\
Total & $593: 220$ & $1.73^{\text {ns }}$ \\
Heterogeneity & & $2.33^{\text {ns }}$ \\
\hline
\end{tabular}

$\mathrm{ns}=$ No significant difference from expected ratio.

Table 8 Joint segregation of the GOT/3 isozyme locus with self-compatibility

\begin{tabular}{l|rr|r}
\multicolumn{3}{c}{ GOT/3 } \\
& \multicolumn{1}{|c|}{$-\mathrm{r}$} & \multicolumn{1}{c|}{} & \\
\hline $\mathrm{SC}(\mathrm{H})$ & 10 & 5 & 15 \\
$\mathrm{SI}$ & 3 & 12 & 15 \\
\hline & 13 & 17 &
\end{tabular}

\begin{tabular}{llll}
\hline & $\begin{array}{l}\chi^{2} \\
(1: 1)\end{array}$ & d.f. & $P$ \\
\hline -c:-- & 0.30 & 1 & ns \\
SC(H):SI & 0.00 & 1 & ns \\
Joint segregation & 5.63 & 1 & $<0.05$ \\
Total & 5.93 & 3 & ns \\
\hline
\end{tabular}

$\mathrm{c}=L$. temulentum-derived allele.

- = L- perenne $/ L$. multiflorum-derived allele.

$\mathrm{SC}(\mathrm{H})=$ Half self-compatible.

$\mathrm{SI}=$ Self-incompatible.

required to obtain adequate numbers of hybrid plants. It therefore follows that no absolute isolation mechanism is commonly present between these members of the Lolium genus which would prevent the introduction of self-compatibility genes into normally self-incompatible plants.

Despite the low numbers of $\mathrm{BC} 1$ plants produced and the poor fertility status of many of these plants, self-compatibility derived from $L$. temulentum was expressed both in terms of pollen/stigma reaction and ultimately in numbers of self seed set. Selfcompatibility was gametophytically controlled as shown by the differential pollen reaction (compatible to incompatible) on the self stigmas. Furthermore, the 
bimodal segregation of self-fertile and selfincompatible plants in both $\mathrm{BC} 1$ and $\mathrm{BC} 2$ generations and the clear half self-compatible pollination in selffertile $\mathrm{BC} 1$ plants indicated that a single gene $(F)$ controls self-compatibility. The poor pollen viability especially in the $\mathrm{BC} 1$ plants can be accounted for by irregularity in chromosome pairing which had been seen to give rise to univalents and unbalanced complements (M. Scanlon personal communication). Seed set was vastly improved in the $\mathrm{BC} 2$ generation as the proportion of RP and, thus, chromosome pairing was increased. The $\mathrm{BC} 2$, with its increased fertility, therefore gives a more realistic picture of the percentage seed set possible in this self-fertile material.

The production of a significant number of selfcompatible plants from self-incompatible $\mathrm{BC} 1$ plants was not further investigated. There was no predictable segregation pattern in these progeny and it is thought that self-compatibility was probably due to polygenic modifiers of the incompatibility system brought into appropriate combinations by recombination of the genetic background (Lundqvist, 1975).

With self-compatibility under single gene control, it is easy to fix it in the homozygous state simply by selfing or intercrossing heterozygous individuals. One hundred per cent pollen-tube growth, indicating homozygosity, was obtained in some $\mathrm{BC} 1 \mathrm{~S} 1$ progeny by the former method.

Two alternative models have been proposed for the control of self-compatibility by a single gene, which can be distinguished from each other by the differing proportions of compatible to incompatible grains expected in backcrosses when the self-fertile $\mathrm{BC} 1$ plants are used as the male parent. Three-quarters compatible pollen reactions are expected in model 2 in all backcross pollinations whereas seven-eighths compatible pollen reactions would have been expected in model 3 in crosses using the self-fertile $\mathrm{BC} 1$ plants as males. The lack of heterogeneity detected between the four classes of backcross pollination gives a clear indication that the $F$ gene is either a mutation of the $S$ or $Z$ locus or is at least tightly linked to one of the incompatibility loci (model 2). This of course could be confirmed by carrying out interpollinations of $\mathrm{BC} 1 \mathrm{~S} 1$ families but, as mentioned previously, the quality of the pollinations was far from adequate for a detailed diallel to be carried out.

The $F$ gene showed significant joint segregation with the GOT/3 isozyme locus, which suggests a loose linkage relationship in the expected phase, where the GOT/3 'c' allele from L. temulentum was coupled with the $L$. temulentum-derived $F$ gene. The estimated recombination frequency was $0.27 \pm 0.08$. The $P G 1 / 2$ locus has been found to be linked to the $S$ locus in
L. perenne (Cornish et al., 1980.) and GOT/3 and PGI/ 2 are known to be on separate chromosomes ( 2 and 6 respectively) (Lewis et al., 1980). From this it can be deduced that the $F$ gene is either allelic to or closely linked to the $Z$ locus on chromosome 2 . Some corroborative evidence of disturbed allelic ratios at the GOT/3 locus in certain $L$. perenne paircrosses suggested that GOT/3 was linked to an incompatibility locus (Hayward \& McAdam, 1976).

One of the incompatibility loci $(S)$ appears to be still functional in the L. temulentum accesssion used in this present study, otherwise segregations would agree with those proposed in model 1 . The discovery of a functional incompatibility locus in a self-fertile species is of considerable significance for the possibility of reconstructing a self-incompatible form from genotypes that possess different self-compatibility loci (Larsen et al., 1973). Functional incompatibility loci would also provide additional evidence for the theory that self-fertile species are derived from self-incompatible ancestors. As the two incompatibility loci in the grass system rely on complementation for their expression, the single incompatibility locus in L. temulentum is unable to act in the absence of a functional product from the mutated locus. The continued existence of the apparently redundant self-incompatibility locus therefore demands the question as to its role: is it a vestige of the original self-incompatibility system or does it carry out another, as yet, unknown function?

\section{Acknowledgement}

D. Thorogood would like to acknowledge receipt of an AFRC Studentship which enabled the work described in this paper to be carried out.

\section{References}

AMEs, o. 1939. Economic Annuals and Human Cultures. Harvard Botany Museum, Harvard, pp. 153.

CORNISH, M. A., HAYWARD, M. D. AND LAWRENCE, M. J. 1980. Selfincompatibility in ryegrass. III. The joint segregation of $S$ and PGI-2 Lolium perenne L. Heredity, 44, 55-62.

FEARON, C. H., HAYWARD, M. D. AND LAWRENCE, M. J. 1983. Selfincompatibility in ryegrasses. V. Genetic control, linkage and seed set in diploid Lolium multiflorum Lam. Heredity, 50, 35-45.

HAYMAN D. C. 1956 . The genetical control of incompatibility in Phalaris caerulescens Desf. Aust. J. Biol. Sci., 9, 321-331.

HAYWARD, M. D. AND MCADAM, N. J. 1976. Genetic control of isoenzyme phenotypes in L. perenne. Rep. Welsh Plt Breed. Stn, 28-29.

HAYWARD, M. D. AND MCADAM, N. J. 1977. Isozyme polymorphism as a measure of distinctiveness and stability in cultivars of Lolium perenne. Z. Pflanzenzucht, 79, 59-68. 
JEFFrey, E. C. 1916. The Anatomy of Woody Plants. Chicago University Press, Chicago.

JENKIN, T. J. 1935. Interspecific and intergeneric hybrids in herbage grasses. II. Lolium perenne $\times$ L. temulentum. J. Genet.., 31, 379-411.

JENKIN, T. J. 1954. Interspecific and intergeneric hybrids in herbage grasses. VI. Lolium italicum $\mathrm{ABr}$ intercrossed with other Lolium types. J. Genet., 52, 282-299.

JONES, R. N. AND JENABZADEH, P. 1981. Variation in self-fertility, flowering time and inflorescence production in inbred Lolium perenne L. J. Agric. Sci., 96, 521-537.

LALOUETTE, J. A. 1967. Growth of grass pollen when exhibited by the callose fluorochrome reaction. Grana Palynologica, 7, 601-603.

LARSEN, J., LARSEN, K., LUNDQVIST, A. AND ØSTERBYE, U. 1973. Complex self-incompatibility systems within the angiosperms and the possibility of reconstructing a self- incompatibility system from different forms within a self-fertile species. Incompat. Newsletter, 3, 79-80.

LEWIS, E. J., HUMPHREYS, M. W. AND CATON, M. P. 1980. Chromosome location of two isozyme loci in Lolium perenne using primary trisomics. Theoret. Appl. Genet., 57, 237-239.

LUNDQVIST, A. 1961. A rapid method for the analysis of incompatibility in grasses. Hereditas, 47, 705-707.

LuNDQvisT, 1975. Complex incompatibility systems in Angiosperms. Proc. Roy. Soc. Lond. Ser. B, 188, 235-245.

NITZSCHE, w. 1983. Inheritance of the mode of fertilization in Lolium spp. Z. Pflanzenzuchtg, 90, 243-248.

STEBBINS, G. L. 1957. Self-fertilization and population variability in plants. Am. Natural., 91, 337-354.

THOROGOOD, D AND HAYWARD, M. D. 1991. The genetic control of self-compatibility in an inbred line of Lolium perenne L. Heredity, 67, 175-182. 